\title{
KARAKTERISASI PUPUK ORGANIK BERBAHAN DASAR KOTORAN HEWAN
}

\author{
The Characterization of Organic Fertilizer from Manure \\ Fatimatuz Zuhro $^{1 *}$, Hasni Ummul Hasanah ${ }^{1}$, Sugeng Winarso ${ }^{2}$, \\ Mohammad Hoesain ${ }^{2}$, Didin Arifandi ${ }^{1}$ \\ 1) Pendidikan Biologi, FP MIPA, IKIP PGRI Jember \\ 2) Program Studi Agroteknologi Fakultas Pertanian Universitas Jember, \\ e-mail: ${ }^{*}$ bundafatim@gmail.com; hasni.uhasanah@gmail.com; winarsosugeng@unej.ac.id; \\ PIAhoesain@yahoo.co.id; arifandididin@gmail.com
}

\begin{abstract}
ABSTRAK
Limbah peternakan, seperti kotoran hewan, jika tidak dimanfaatkan dengan bijaksana dapat menimbulkan dampak negatif bagi lingkungan berupa pencemaran udara, air dan tanah, menjadi sumber penyakit, dapat memicu peningkatan gas metan dan juga gangguan pada estetika dan kenyamanan lingkungan. Oleh karena itu, diperlukan upaya untuk memanfaatkan limbah peternakan menjadi produk yang berguna, di antaranya menjadikannya sebagai pupuk organik. Penelitian ini bertujuan untuk mengetahui apakah pupuk organik berbahan dasar kotoran hewan memiliki karakter sesuai dengan pupuk organik SNI (Standart Nasional Indonesia-2011). Penelitian ini menggunakan rancangan penelitian deskriptif. Data penelitian diperoleh melalui analisis laboratorium beberapa sampel pupuk organik berbahan dasar kotoran hewan dan membandingkan hasilnya dengan standart pupuk organik SNI-2011. Berdasarkan hasil penelitian menunjukkan bahwa pupuk organik yang dihasilkan pada penelitian ini telah sesuai dengan SNI -2011, kecuali pada kadar air dan unsur hara makro (N, P, dan K). Kadar air masih harus diturunkan agar sesuai dengan SNI-2011. Selain itu, masih perlu upaya untuk meningkatkan kandungan unsur hara makro pada pupuk organik berbahan dasar kotoran hewan agar sesuai dengan SNI-2011.
\end{abstract}

Kata kunci : Karakterisasi, kotoran hewan, pupuk organik, SNI-2011.

\section{ABSTRACT}

Farm's waste, such as manure, if it is not utilized wisely can cause negative impact towards the environment in the form of air, water and land pollution. It becomes the source of the diseases, which can trigger the increase of methane gas and also disturbance to esthetics and environmental comfort. Therefore, an effort is needed to harness farm's waste in order to make them becomes useful products; one of them is by turning them becomes organic fertilizer. This research has a purpose to know whether organic fertilizer from manure has appropriate character with SNI (Standart Nasional Indonesia)-2011 organic fertilizer. This research used descriptive research design. The data of the research were obtained through laboratory analysis of several samples from organic fertilizers from manure and compared the result with SNI-2011 organic fertilizer standard. Based on the research result, it showed that biological organic fertilizer which is produced in this research has been appropriate to SNI-2011, except in the water content and macro nutrient (N, P, and $K)$. The water content must be decreased and the macro nutrient must be increased in order to make it appropriate to SNI-2011.

Keywords: Characterization, manure, organic fertilizer, SNI-2011. 


\section{PENDAHULUAN}

Limbah ternak merupakan hasil buangan dari kegiatan usaha peternakan yang saat ini jumlahnya semakin meningkat seiring dengan peningkatan usaha peternakan di Indonesia. Limbah tersebut dapat menimbulkan berbagai macam dampak negatif apabila tidak ditindaklanjuti dengan cara bijaksana. Berdasarkan laporan yang dikeluarkan oleh Direktorat Jenderal Pengendalian Pencemaran dan Kerusakan Lingkungan Kementrian Lingkungan Hidup dan Kehutanan (KLHK), di tahun 2015 hampir 68\% atau mayoritas mutu air sungai di 33 provinsi di Indonesia dalam status tercemar akibat limbah domestik, limbah peternakan, industri, dan limbah pertanian (Sudiarto, 2008). Oleh karena itu, masih diperlukan upaya untuk memanfaatkan limbah ternak menjadi suatu produk yang berguna dan tidak berbahaya bagi lingkungan.

Limbah ternak masih mengandung nutrisi yang potensial untuk dijadikan pupuk organik. Kotoran sapi merupakan salah satu contoh bahan potensial untuk membuat pupuk organik. Satu ekor sapi setiap harinya menghasilkan kotoran berkisar $8-10 \mathrm{~kg}$ atau $2.6-3.6$ ton per tahun, sehingga apabila dimanfaatkan menjadi pupuk organik akan dapat mengurangi penggunaan pupuk anorganik/kimia (Budiyanto, 2011). Pertumbuhan permintaan produk pertanian organik di seluruh dunia mencapai rata-rata $20 \%$ per tahun. Data WTO (World Trade Organisation) menunjukkan bahwa selama periode 2000-2004 perdagangan produk pertanian organik telah mencapai nilai rata-rata 17.5 miliar dolar AS (Kasworo, 2013). Oleh karena itu, pemanfaatan limbah ternak menjadi pupuk organik merupakan suatu solusi alternatif bagi keberadaan limbah ternak yang selama ini berdampak negatif bagi lingkungan.

Pupuk organik merupakan hasil akhir penguraian sisa-sisa tumbuhan dan hewan yang telah lapuk dan hancur dengan sendirinya, seperti; daun-daunan, batang, ranting, sisa-sisa makanan, dan kotoran hewan (Hariatik, 2014). Kotoran hewan, seperti kotoran sapi, kotoran ayam, dan kotoran kambing memiliki unsur hara yang sangat bagus bagi pertumbuhan dan perkembangan tanaman. Kotoran hewan lebih kaya akan berbagai unsur hara dan mikroba dibandingkan dengan limbah dari tanaman. Kadar unsur hara setiap kotoran hewan berbedabeda, tergantung jenis makanannya. Sebagian besar kotoran hewan rata-rata mengandung $0.5 \% \mathrm{~N}, 0.25 \% \mathrm{P}_{2} \mathrm{O}_{5}$, dan $0.5 \% \mathrm{~K}_{2} \mathrm{O}$, sehingga dalam 1 ton kotoran hewan menyumbangkan

$5 \mathrm{~kg} \mathrm{~N}, 2.5 \mathrm{~kg} \mathrm{P}_{2} \mathrm{O}_{5}$, dan $5 \mathrm{~kg} \mathrm{~K}_{2} \mathrm{O}$ (Hapsari, dkk., 2013). Penggunaan pupuk organik pada proses budidaya tanaman dapat meningkatkan kesuburan tanah, menambah jumlah unsur hara tanah yang dibutuhkan tanaman, dan mendukung proses pertanian yang berkelanjutan. Hasil 
penelitian Siwanto, dkk (2015) menunjukkan bahwa aplikasi pupuk organik dapat meningkatkan efisiensi pemupukan anorganik pada budidaya padi sawah.

Berdasarkan informasi tersebut, penelitian ini bertujuan untuk memproduksi pupuk organik berbahan dasar kotoran hewan dalam rangka memanfaatkan limbah organik ternak. Pupuk organik yang dihasilkan akan dikarakterisasi melalui analisis di laboratorium untuk diuji kandungan unsur hara yang ada di dalamnya. Pupuk organik yang dihasilkan diharapkan memenuhi kriteria pupuk organik berdasarkan SNI -2011.

\section{METODE PENELITIAN}

Penelitian ini dilaksanakan di lahan pembuatan pupuk di desa Gumukmas, kabupaten Jember, Jawa Timur. Bahan-bahan yang digunakan dalam penelitian ini, antara lain : kotoran sapi, kotoran kambing, kotoran ayam, cairan rumen sapi, tetes tebu, air, terasi, dan bekatul. Sedangkan alat-alat yang digunakan, antara lain; timbangan, cangkul, tempat fermentasi, tempat inkubasi pupuk organik, alat penghancur (chooper), alat pemanas, panci, wadah inkubasi, termometer, dan alat pengaduk.

Kegiatan penelitian meliputi; (1). Pembuatan bioaktivator dari cairan rumen sapi, (2). Pembuatan pupuk organik, dan (3). Analisis kandungan unsur hara dalam pupuk organik.

Bioaktivator dibuat dari beberapa bahan, antara lain; bekatul halus $1 \mathrm{~kg}$, tetes tebu (molase) 1 liter, terasi $1 \frac{1}{4} \mathrm{~kg}$ diiris tipis, cairan pada rumen sapi, dan air 2 liter. Bioaktivator dibuat dengan cara merebus air dan tetes tebu. Selanjutnya terasi dimasukkan dalam air rebusan tersebut, bekatul juga dimasukkan sedikit demi sedikit. Rebusan diaduk sekitar 1 jam. Kemudian rebusan didinginkan dan dimasukkan dalam timba. Setelah itu cairan rumen sapi dimasukkan dalam rebusan yang telah dingin. Kemudian campuran tersebut ditutup plastik transparan sekitar 10 hari. Setelah 10 hari biasanya bioaktivator sudah jadi yang ditandai dengan baunya yang harum dan warnanya tidak keruh. Kemudian, adonan dalam timba disaring, dimasukkan dalam botol, dan ditutup rapat.

Pembuatan pupuk organik dari kotoran hewan dilakukan dengan sistem anaerob. Bahan pupuk organik dengan total berat $500 \mathrm{~kg}$ ditumpuk dalam suatu tempat, disiram dengan bioaktivator sampai $50 \%$ permukaannya basah, ditutup dengan plastik terpal, dan didiamkan sampai pupuk organik matang/jadi. Setiap 3 hari sekali atau saat suhu bahan pupuk semakin tinggi (kondisional), dilakukan pembalikan untuk menstabilkan suhu.

Analisis laboratorium dilakukan pada beberapa parameter, antara lain; C organik (\%) dengan metode pengabuan, rasio $\mathrm{C} / \mathrm{N}$ dengan membandingkan kandungan $\mathrm{C}$ terhadap $\mathrm{N}$, 
material ikutan dengan menghitung jumlah bahan ikutan seperti; kaca, plastik, kerikil, dan sebagainya (\%), kadar air (\%) dengan metode gravimetri, logam berat (ppm) dengan analisis penetapan logam, $\mathrm{pH}$ dengan pHmeter, unsur hara makro $\left(\mathrm{N}_{2} \mathrm{P}_{2} \mathrm{O}_{5}\right.$, dan $\left.\mathrm{K}_{2} \mathrm{O}\right)$ dan unsur hara mikro (Fe, Mn, dan $\mathrm{Zn}$ ) dengan metode pengabuan basa, serta mikroba kontaminan (E. coli dan Salmonella $s p$ ) dan mikroba fungsional (penambat $\mathrm{N}$ dan pelarut $\mathrm{P}$ ) dengan metode penetapan populasi mikroba.

\section{HASIL DAN PEMBAHASAN}

\section{Karakter Fisik Pupuk Organik Berbahan Dasar Kotoran Hewan}

Karakter fisik dari pupuk organik pada penelitian ini secara rinci dapat dilihat pada Tabel 1. sebagai berikut:

Tabel 1. Karakter fisik pupuk organik berbahan dasar kotoran hewan

\begin{tabular}{|c|c|c|c|}
\hline No. & Karakter Fisik & Keterangan & SNI-2011 \\
\hline 1. & Kenampakan luar & $\begin{array}{l}\text { Warna hitam kecoklatan, tidak } \\
\text { lengket, tidak berbau, dan } \\
\text { bertekstur remah/gembur }\end{array}$ & - \\
\hline 2. & Bahan ikutan & $1 \%$ & Maks. $2 \%$ \\
\hline
\end{tabular}

Secara fisik pupuk organik dengan bahan baku kotoran hewan yang dihasilkan dalam penelitian ini memiliki warna hitam kecoklatan, tidak lengket, tidak berbau, dan bertekstur remah atau gembur (Gambar 1.). Kriteria tersebut menunjukkan bahwa pupuk organik dari kotoran hewan yang dihasilkan telah matang atau siap digunakan. Pupuk organik pada penelitian ini hanya membutuhkan waktu selama 7 hari untuk menjadi matang atau siap digunakan. Kotoran hewan yang digunakan sebagai bahan pupuk organik dalam penelitian ini (ayam, kambing, dan sapi) telah kering sebelum dicampur. Kondisi tersebut membuat proses fermentasi bahan organik lebih cepat, sehingga pupuk organik lebih cepat matang. Selain itu, penambahan bioaktivator dalam proses pembuatan pupuk organik juga sangat berperan dalam mempercepat proses degradasi bahan organik di dalam bahan pupuk. Mikroba yang terdapat dalam bioaktivator akan membantu menguraikan ikatan-ikatan kimia kompleks menjadi sederhana, sehingga proses pembuatan pupuk organik menjadi lebih cepat jika dibandingkan dengan tanpa menggunakan bioaktivator (Arisha, et al., 2003). 


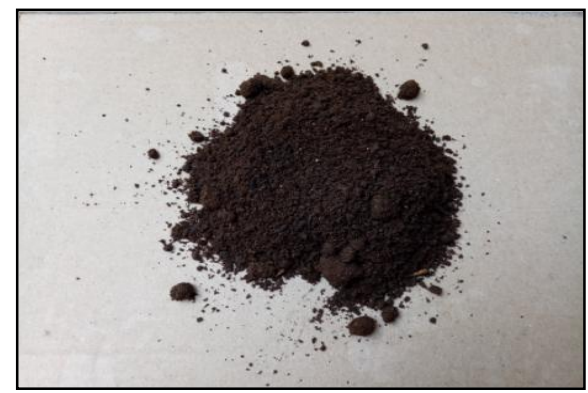

Gambar 1. Kenampakan fisik pupuk organik berbahan dasar kotoran hewan

Pada penelitian ini, pupuk organik yang dihasilkan memiliki kadar bahan ikutan sebesar 1\%. Hal ini telah sesuai dengan standart pupuk organik SNI-2011, yang mengharuskan pupuk organik tidak boleh mengandung bahan ikutan lebih dari 2\% (Isro'i, 2015). Bahan ikutan yang biasanya muncul dalam pupuk organik, antara lain; kaca, plastik, dan kerikil. Semakin sedikit bahan ikutan dalam pupuk organik menunjukkan bahwa pupuk organik memiliki kualitas yang baik.

\section{Karakter Kimia Pupuk Organik Berbahan Dasar Kotoran Hewan}

Karakter kimia yang dimaksud dalam pembahasan ini meliputi kadar air, pH, persentase $\mathrm{C}$, rasio $\mathrm{C} / \mathrm{N}$, kandungan logam berat, serta kandungan unsur hara makro dan mikro (Tabel 2.).

Tabel 2. Karakter kimia pupuk organik berbahan dasar kotoran hewan

\begin{tabular}{|c|c|c|c|c|}
\hline No. & Karakter Kimia & Satuan & Keterangan & SNI-2011 \\
\hline 1. & Kadar air & $\%$ & 29 & $15-25$ \\
\hline 2. & $\mathrm{pH}$ & - & 7 & $4-9$ \\
\hline 3. & $\mathrm{C}$ & $\%$ & 29 & Min 15 \\
\hline 4. & Rasio C/N & & 15 & $15-25$ \\
\hline 5. & $\begin{array}{l}\text { Kandungan logam berat } \\
\text { Cadmium }(\mathrm{Cd})\end{array}$ & ppm & 2 & Maks 2 \\
\hline 6. & $\begin{array}{l}\text { Kandungan unsur hara } \\
\text { makro }\left(\mathrm{N}+\mathrm{P}_{2} \mathrm{O}_{5}+\mathrm{K}_{2} \mathrm{O}\right)\end{array}$ & $\%$ & 1.4 & Min. 4 \\
\hline 7. & $\begin{array}{l}\text { Kandungan unsur hara } \\
\text { mikro (Fe dan } \mathrm{Mn})\end{array}$ & ppm & $\begin{array}{l}\mathrm{Fe}: 265 \\
\mathrm{Mn}: 8.94\end{array}$ & Maks. 5000 \\
\hline
\end{tabular}

Berdasarkan hasil analisis laboratorium, sampel pupuk organik dari kotoran hewan memiliki kadar air sebesar 29\%. Angka ini lebih tinggi dari standart pupuk organik SNI2011, yaitu antara 15-25\% (Isro'i, 2015). Kadar air ini terkait dengan status kelembapan pupuk organik. Kelembapan memiliki peran yang sangat penting dalam proses metabolisme 
mikroba dan secara tidak langsung berpengaruh pada suplai oksigen. Pada kelembapan yang optimal, metabolisme mikroba berjalan dengan baik sehingga mendukung proses dekomposisi bahan organik dalam pembuatan pupuk organik. Mikroorganisme dapat memanfaatkan bahan organik apabila bahan organik tersebut larut di dalam air (Dewi, 2012). Kadar air yang lebih tinggi dari standart pada pupuk organik dapat diturunkan dengan proses pengeringan (Suriadikarta, 2014).

Faktor derajat keasaman $(\mathrm{pH})$ juga sangat berperan dalam proses dekomposisi semi anaerob. Pengamatan $\mathrm{pH}$ bertujuan sebagai sebuah indikator dalam proses dekomposisi pupuk organik. Pupuk organik yang dihasilkan dalam penelitian ini memiliki pH sebesar 7. Nilai tersebut telah sesuai dengan standart pupuk organik SNI-2011 yang mengharuskan kisaran pH pada pupuk organik antara 4-9 (Isro'i, 2015). Mikroba di dalam pupuk organik akan bekerja pada keadaan $\mathrm{pH}$ netral sampai sedikit asam. Derajat keasaman yang optimum untuk pertumbuhan bakteri pegoksidasi ammonia yang bersifat autotrofik berkisar dari 7.5 sampai 8.5 (Ratledge, 1994 dalam Agustiyani, 2004). Supadma (2008) dalam Widarti, dkk. (2015) menyatakan bahwa peningkatan $\mathrm{pH}$ terjadi akibat terurainya protein dan terjadinya pelepasan ammonia dalam pupuk organik.

Pada hasil penelitian ini, persentase bahan organik (\% C) dalam pupuk organik dari kotoran hewan mencapai angka 29\%. Angka tersebut telah sesuai dengan standart pupuk organik SNI-2011, yaitu minimal 15\% (Isro'i, 2015). Kandungan bahan organik (C-organik) berperan penting dalam bidang pertanian, karena bahan organik dapat mengatur berbagai sifat tanah (fisik, kimia dan biologi) dan sebagai penyangga persediaan unsur-unsur hara bagi tanaman. Kualitas bahan organik sangat menentukan kecepatan proses dekomposisi dan mineralisasi bahan organik (Suhardjadinata, 2016).

Parameter lain yang berhubungan dengan bahan organik adalah rasio $\mathrm{C} / \mathrm{N}$. Proses pengomposan adalah suatu proses penguraian bahan organik dari rasio $\mathrm{C} / \mathrm{N}$ tinggi menjadi rasio $\mathrm{C} / \mathrm{N}$ rendah dengan upaya mengaktifkan mikrobia perombak atau pendekomposer (bakteri, fungi, dan actinomicetes). Pada penelitian ini rasio $\mathrm{C} / \mathrm{N}$ pupuk organik yang dihasilkan sebesar 15. Angka tersebut telah sesuai dengan kriteria rasio $\mathrm{C} / \mathrm{N}$ pupuk organik SNI-2011 yaitu antara 15-25 (Isro’i, 2015). Tingkat rasio C/N dipergunakan untuk menilai kematangan kompos yang dihasilkan selama proses pengomposan. Selain itu, rasio C/N dapat digunakan untuk memprediksi laju mineralisasi bahan organik (Suhardjadinata, 2016). Rasio $\mathrm{C} / \mathrm{N}$ sebesar 15 menunjukkan bahwa pupuk organik dalam kondisi matang dan dapat digunakan sebagai sumber nutrisi bagi tanaman. 
Faktor lain yang menentukan kualitas pupuk organik adalah keberadaan logam berat. Semakin rendah kandungan logam berat pada pupuk organik menunjukkan kualitasnya yang bagus, begitu pula sebaliknya. Logam berat berdampak negatif terhadap kondisi fiologis tanaman dan juga ternak apabila absorbsinya telah melebihi batas toleransi yang telah ditentukan (Irwan, 2015). Pupuk organik dari kotoran hewan pada penelitian ini mengandung logam berat sebesar 2 ppm. Angka tersebut merupakan batas maksimal kandungan logam berat yang diperbolehkan berdasarkan standart pupuk organik SNI-2011.

Faktor penting lain yang harus ada pada pupuk organik adalah kandungan unsur hara, baik unsur hara makro atau mikro. Unsur hara makro adalah unsur hara yang dibutuhkan dalam jumlah banyak untuk mendukung proses pertumbuhan dan perkembangan tanaman. Pada penelitian ini, pupuk organik dari kotoran hewan mengandung persentase total hara makro $\left(\mathrm{N}+\mathrm{P}_{2} \mathrm{O}_{5}+\mathrm{K}_{2} \mathrm{O}\right)$ sebesar 1.4. Angka tersebut masih berada di bawah angka yang seharusnya dimiliki pupuk organik berdasarkan SNI-2011, yaitu minimal 4 (Isro'i, 2015). Oleh karena itu, masih diperlukan usaha untuk meningkatkan kandungan unsur hara makro pada pupuk organik berbahan dasar kotoran hewan. Upaya tersebut dapat dilakukan dengan beberapa cara, antara lain; dengan menambahkan bahan organik yang kaya akan unsur N, P, dan K seperti; limbah ikan (sebagai sumber N) (Syukron, 2018), batuan phosfat (sebagai sumber P) (Batubara, dkk., 2014), dan batuan leusit (sebagai sumber K) (WKA, et al., 2010). Selain itu, pada umumnya petani masih menambahkan pupuk anorganik untuk meningkatkan kandungan hara makro pada pupuk organik dalam proses budidaya tanaman. Hasil penelitian juga menunjukkan bahwa kombinasi pemupukan pupuk organik dengan pupuk anorganik ternyata dapat meningkatkan efisiensi pemupukan pada beberapa tanaman budidaya, seperti; tomat, padi, dan kelapa sawit (Pangaribuan, dkk, 2011; Tustiyani, I., dkk, 2014; Siwanto, T., dkk., 2015; Sari, V. I., dkk., 2015).

Selain unsur hara makro, pupuk organik juga harus mengandung unsur hara mikro. Unsur hara mikro merupakan unsur hara yang dibutuhkan tanaman dalam jumlah kecil, tetapi apabila terjadi defisiensi salah satu unsur hara mikro maka tanaman tidak dapat tumbuh secara optimal (Adelia, dkk., 2013). Pada penelitian ini, pupuk organik dari kotoran hewan mengandung unsur hara mikro Fe sebesar 265 ppm dan Mn sebesar 8.94 ppm. Angka ini telah sesuai dengan standart pupuk organik SNI-2011, yang mengharuskan pupuk organik memiliki kadar unsur hara mikro maksimal sebesar 500 ppm untuk Fe dan 5000 ppm untuk Mn (Isro'i, 2015). 


\section{Karakter Biologi Pupuk Organik Berbahan Dasar Kotoran Hewan}

Karakter biologi pada pupuk organik terkait dengan keberadaan mikroba fungsional dan mikroba kontaminan (Tabel 3.).

Tabel 3. Karakter biologi pupuk organik berbahan dasar kotoran hewan

\begin{tabular}{cccl}
\hline No. & Karakter Biologi & Keterangan & SNI-2011 \\
\hline 1. & Mikroba fungsional $\left(\mathrm{cfu}^{-\mathrm{g}}\right)$ & $6.8 \times 10^{6} \mathrm{cfu}^{-\mathrm{g}}$ & Min. 1000 $\mathrm{cfu}^{-\mathrm{g}}$ \\
2. & Mikroba kontaminan $\left(\mathrm{cfu}^{-\mathrm{g}}\right)$ & 0 & Maks. 100 $\mathrm{cfu}^{-\mathrm{g}}$ \\
\hline
\end{tabular}

Mikroba fungsional merupakan mikroba yang memiliki peranan penting dalam proses dekomposisi bahan organik dalam bahan pupuk. Mikroba fungsional meliputi; mikroba penambat $\mathrm{N}$ dan mikroba pelarut $\mathrm{P}$. Secara alamiah kedua mikroba tersebut ada di dalam bahan organik yang mengalami proses dekomposisi (Sahwan, 2016). Pupuk organik berbahan dasar kotoran hewan memiliki kandungan mikroba penambat $\mathrm{N}$ dan pelarut $\mathrm{P}$ yang sama, yaitu sebesar $6.8 \times 10^{6} \mathrm{cfu}^{-\mathrm{g}}$. Hal ini telah sesuai dengan standart pupuk organik SNI2011 yang menghendaki pupuk organik memiliki kandungan mikroba fungsional minimal $1000 \mathrm{cfu}^{-\mathrm{g}}$ (Isro'i, 2015). Berdasarkan angka tersebut terlihat bahwa pupuk organik dari kotoran hewan memiliki mikroba fungsional yang relatif lebih banyak dari yang diharapkan dalam SNI-2011.

Selain mengandung mikroba fungsional, pada pupuk organik juga terdapat kemungkinan keberadaan mikroba kontaminan. Mikroba kontaminan yang biasa terdapat pada pupuk organik, antara lain E. coli dan Salmonella sp. Kedua jenis mikroba tersebut termasuk jenis mikroba yang patogen, dan keberadaannya dijadikan sebagai parameter adanya bakteri patogen yang lain (Sahwan, 2016). Berdasarkan analisis laboratorium menunjukkan bahwa pupuk organik yang dihasilkan dalam penelitian ini tidak mengandung mikroba kontaminan. Standart pupuk organik SNI-2011 menyatakan bahwa pupuk organik tidak boleh mengandung mikroba kontaminan (E. coli dan Salmonella sp.) lebih besar dari $100 \mathrm{cfu}^{-\mathrm{g}}$ (Isro'i, 2015). Keberadaan mikroba kontaminan tersebut dikhawatirkan dapat berpengaruh pada kesehatan manusia sebagai konsumen produk pertanian.

\section{KESIMPULAN}

Berdasarkan hasil penelitian menunjukkan bahwa pupuk organik yang dihasilkan pada penelitian ini telah sesuai dengan SNI -2011, kecuali pada kadar air dan unsur hara makro (N, P, dan K). Kadar air masih harus diturunkan agar sesuai dengan SNI-2011. Selain 
itu, masih perlu upaya untuk meningkatkan kandungan unsur hara makro pada pupuk organik berbahan dasar kotoran hewan agar sesuai dengan SNI-2011.

\section{UCAPAN TERIMA KASIH}

Terimakasih kepada semua pihak yang telah membantu dalam penelitian ini, khususnya kepada RISTEKDIKTI sebagai donatur pada pelaksanaan penelitian ini.

\section{DAFTAR PUSTAKA}

Adelia, P. F., Koesriharti, dan Sunaryo. 2013. Pengaruh Penambahan Unsur Hara Mikro (Fe dan $\mathrm{Cu}$ ) dalam Media Paitan Cair dan Kotoran Sapi Cair terhadap Pertumbuhan dan Hasil Bayam Merah (Amaranthus tricolor L.) dengan Sistem Hidroponik Rakit Apung. Jurnal Produksi Tanaman. 1 (3): 1-11.

Agustiyani, D., Hartati, I., Erni, N. F., dan Oedjijono. 2004. Pengaruh pH dan Substrat Organik terhadap Pertumbuhan dan Aktivitas Bakteri Pengoksida Ammonia. Biodiversitas. 5(2): 43-47.

Arisha, H. M. E., Gad, A., A., and Younes, S. E. 2003. Response of Some Pepper Cultivar to Organic and Mineral Nitrogen Fertilizer Under Sandy Soil Condition. Zagazig J. Agric. Res. Vol. 30: 1875-1899.

Batubara, I. S., Fauzi, and Kemala, S.R. 2014. Pengaruh Pemberian Fosfat Alam dan Bahan Organik terhadap Sifat Kimia Tanah, Pertumbuhan dan Produksi Padi (Oryza sativa L.) pada Tanah Sulfat Masam Potensial. Jurnal Online Agroteknologi. Vol. 2 (3): 1251-1259.

Budiyanto M. A. K. 2011. Tipologi Pendayagunaan Kotoran Sapi dalam Upaya Mendukung Pertanian Organik di Desa Sumbersari Kecamatan Poncokusumo Kabupaten Malang. Jurnal UMM. 7 (1).

Dewi Y. S. dan Tresnowati. 2012. Pengolahan Sampah Skala Rumah Tangga Menggunakan Metode Komposting. Jurnal Ilmiah Fakultas Teknik LIMIT'S. (8):2.

Hapsari A., Y. 2013. Kualitas dan Kandungan Pupuk Organik Limbah Serasah dengan Inokolum Kotoran Sapi Secara Semianaeorob. [Skripsi]. Surakarta (ID): Universitas Muhammadiyah Surakarta.

Hariatik. 2014. Perbandingan Unsur NPK pada Pupuk Organik Kotoran Sapi dan Kotoran Ayam dengan Pembiakan Mikroorganisme Lokal (MOL). Jurnal FKIP UNS. Kediri.

Irwan M, Syamsuddin H, dan Asmuddin, N. 2015. Efektivitas Penggunaan Pupuk Organik dalam Mereduksi Kandungan Logam Berat Rumput Mulato Pada Tanah Pasca Tambang. Jurnal Sains dan Teknologi. 15 (1).

Isroi. 2015. Peraturan Menteri Pertanian Nomor 70/Permentan/SR.140/10/2011 (Online): http://perundangan.pertanian.go.id. Accessed on 10 January 2016.

Kasworo, A., Munifatul, I., dan Kismartini. 2013. Daur Ulang Kotoran Ternak sebagai Upaya Mendukung Peternakan Sapi Potong yang Berkelanjutan di Desa Jogonayan 
Kecamatan Ngablak Kabupaten Magelang. Prosiding Seminar Nasional Pengelolaan Sumberdaya Alam dan Lingkungan. Universitas Diponegoro. Semarang.

Pangaribuan, D. H., Octa, L. P., dan Lismawati. 2011. Pengurangan Pemakaian Pupuk Anorganik dengan Penambahan Bokashi Serasah Tanaman pada Budidaya Tanaman Tomat. J. Agron. Indonesia 39 (3): 173-179.

Sahwan F L. 2016. Kaji Terap Teknologi Komposting untuk Penanganan Limbah Ternak Sapi Potong. Jurnal Teknologi Lingkungan. (17):2.

Sari, V. I., Sudradjat, dan Sugiyanta. 2015. Peran Pupuk Organik dalam Meningkatkan Efektivitas Pupuk NPK pada Bibit Kelapa Sawit di Pembibitan Utama. J. Agron. Indonesia 43 (2) : 153-160.

Siwanto, T., Sugiyanto, dan M. Melati. 2015. Peran Pupuk Organik dalam Peningkatan Efisiensi Pupuk Anorganik pada Padi Sawah (Oryza sativa L.). J. Agron. Indonesia 43 (1): 8-14.

Sudiarto, B. 2008. Pengelolaan Limbah Peternakan Terpadu dan Agribisnis yang Berwawasan Lingkungan. Seminar Nasional Teknologi Peternakan dan Veteriner. Fakultas Peternakan Universitas Padjadjaran Bandung.

Suhardjadinata dan Dwi P. 2016. Proses Produksi Pupuk Organik Limbah Rumah Potong Hewan dan Sampah Organik. Jurnal Siliwangi. 2 (2).

Suriadikarta, D. A., dan Diah, S. 2014. Baku Mutu Pupuk Organik. Pupuk Organik dan Pupuk Hayati (2): 231-244.

Syukron, F. 2018. Pembuatan Pupuk Organik Bokhasi dari Tepung Ikan Limbah Perikanan Waduk Cirata. Jurnal Sungkai. Vol. 5 (1): 1-16.

Tustiyani, I., Sugiayanta, dan M. Melati. 2014. Karakter Morfofisiologi dan Fisikokimia Beras dengan Berbagai Dosis Pemupukan Organik dan Hayati pada Budidaya Padi Organik. J. Agron. Indonesia 42 (3): 187-194.

Widarti, B.N., Wardah, K.W., dan Edhi, S. 2015. Pengaruh Rasio C/N Bahan Baku pada Pembuatan Kompos dari Kubis dan Kulit Pisang. Jurnal Integrasi Proses. 5 (2): 7580 .

WKA, A., Sri, H., and Hery, W. 2010. Pengaruh Pemberian Butir Leusit dan Konsentrasi $\mathrm{HNO}_{3}$ terhadap Ketersediaan K Entisols Bengawan Solo dengan Indikator Tanaman Kacang Tanah (Arachis hypogea L.). Sains Tanah. Vol. 7 (1): 9-16. 